\title{
Equity and Justice in Climate Change Adaptation: Policy and Practical Implication in Nigeria
}

\author{
Chinwe Philomina Oramah and Odd Einar Olsen
}

\section{Contents}

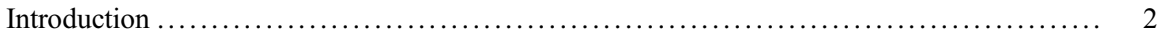

Conceptualizing Justice and Equity as It Relates to Climate Change Adaptation $\ldots \ldots \ldots \ldots \ldots$. 4

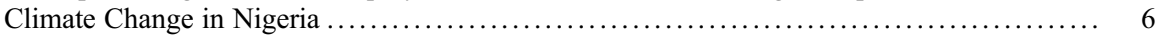

Preparing for Climate Change Adaptation in Nigeria ........................... 6

Exploring the Equity and Justice Perspective of Climate Change Adaptation in Nigeria ... 7

Vulnerability and Impact of Climate Change in Nigeria ............................. 9

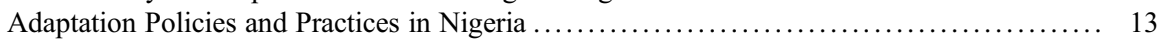

Policy Implications of Adaptation Governance in Nigeria ........................ 13

Actors Perspective on Adaptation Governance in Nigeria ........................... 14

Equity and Justice in Adaptation Policies and Practices in Nigeria .................. 15

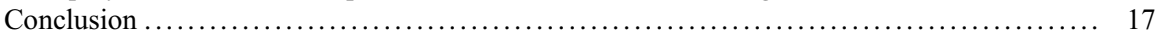

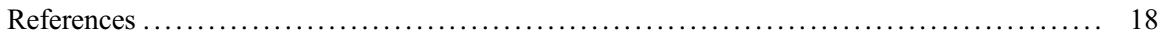

\section{Abstract}

Over the past decade, justice and equity have become a quasi-universal answer to problems of environmental governance. The principles of justice and equity emerged as a useful entry point in global governance to explore the responsibilities, distribution, and procedures required for just climate change adaptation. These principles are designed primarily through the establishment of funding mechanisms, top-down guides, and frameworks for adaptation, and other adaptation instruments from the UNFCCC process, to ensure effective adaptation for vulnerable countries like Nigeria that have contributed least to the issue of

This chapter was previously published non-open access with exclusive rights reserved by the Publisher. It has been changed retrospectively to open access under a CC BY 4.0 license and the copyright holder is "The Author(s)". For further details, please see the license information at the end of the chapter.

C. P. Oramah $(\bowtie) \cdot$ O. E. Olsen

Department of Safety, Economics, and Planning, University of Stavanger, Stavanger, Norway

e-mail: chinwe.p.oramah@uis.no; oddeinar.olsen@uis.no 
climate change but lack adaptive capacity. Global adaptation instruments have been acknowledged for adaptation in Nigeria. Climate change has a detrimental impact on Nigeria as a nation, with the burden falling disproportionately on the local government areas. As Nigeria develop national plans and policies to adapt to the consequences of climate change, these plans will have significant consequences for local government areas where adaptation practices occur. Although the local government's adaptation burden raises the prospects for justice and equity, its policy and practical implication remains less explored. This chapter explores the principles of justice and equity in national adaptation policy and adaptation practices in eight local government areas in southeast Nigeria. The chapter argues that some factors make it challenging to achieve equity and justice in local adaptation practices. With the use of a qualitative approach (interview $(\mathrm{n}=52)$, observation, and document analysis), this chapter identified some of the factors that constraints equity and justice in local government adaptation in southeast Nigeria.

\section{Keywords}

Adaptation policy $\cdot$ adaptation practices $\cdot$ environmental justice $\cdot$ equity $\cdot$ Nigeria $\cdot$ local level

\section{Introduction}

The gap between the developed and developing nations as regards development is extending to the risks and security issue of climate change. While almost all countries are affected by the risk and security impacts of climate change, it is widely recognized that developing countries are more vulnerable, lacks adaptive capacity (Tabbo and Amadou 2017), and would suffer disproportionately (Stallworthy 2009; Rübbelke 2011). This is particularly the case for developing countries in Africa living in poverty (IPCC 2014). Wide recognition that industrialized countries are overwhelmingly responsible for climate change has slowly led to conceptualizing adaptation as a global issue with a formidable dilemma of equity and justice in developing countries such as Nigeria (McManus et al. 2014; Thomas and Twyman 2005). Scaling adaptation as a global issue recognizes an international responsibility to provide financial support and funding for undertaking adaptation at the national or local level in developing countries (Benzie and Persson 2019; Ciplet et al. 2013; Saraswat and Kumar 2016). Despite the funds obtained by some developing countries for climate change adaptation, implementing adaptation at the local level continues to be challenging.

Many of the impacts of climate change, such as floods and drought, are experienced at the local level (Rauken et al. 2015). As a result, the burden of climate change adaptation practices falls disproportionately on the local government area. Adaptation is a localized phenomenon that addresses local circumstances with the need for local solutions and actions (Corfee-Morlot et al. 2011; Measham et al. 2011; 
Moore 2012; Nalau et al. 2015). Conceptualizing climate change adaptation as a local phenomenon is based on the principle of subsidiarity, which is a belief that tasks should be trusted with the lowest level, where the local actors are always able and willing to govern their natural resources effectively (Lockwood et al. 2009). This approach to adaptation assumes that local actors have the required resources to practice adaptation in isolation.

However, local government in Nigeria is embedded in a broader multiscale governance context comprising a range of government actors from the state, the federal, and global levels. Thus, current thinking poses that adaptation plans should be understood and developed at national and subnational levels, practiced at the local level, and funded via international institutions (Benzie and Persson 2019). As a result, local adaptation is increasingly supporting and driving adaptation initiatives and policies within the framework provided by national and state-level legislation (Vogel and Henstra 2015). The extent to which these adaptation policies consider vulnerabilities and impacts of climate change at the local level as well as the extent to which local government participates in instituting national adaptation policies and frameworks are debatable. Against this backdrop, different scholarly voices have emerged over the years, arguing that adaptation decision-making at policy and practical levels has justice and equity implications (Few et al. 2007; Paavola and Adger 2006; Thomas and Twyman 2005).

Nigeria has instituted national adaptation plans and policies as well as established climate change institutions to aid adaptation. Despite the adaptation policies and institutions, some local government areas struggle to cope with and respond to climatic impacts. This is because there are no regulations and institutions designed to foster climate change adaptation in the local government area (Oulu 2015). Presently, the local government institutions carrying out adaptation, such as the ministry of environment and planning, department of works, and local emergency management agency (LEMA), are not designed for climate change challenges. This chapter discusses prospects for justice and equity principles in Nigeria's national adaptation policy and local adaptation practices. This chapter affirms that equity and justice are the important normative goal in both national and local climate change adaptation, but argue that the practice of equity and justice in climate change adaptation is often embedded in the illusion of inclusion. Without due consideration of equity and justice at all levels of governance, there would be a tension between the underlying principle of fair adaptation and participation by the local governments and vulnerable groups in Nigeria. Alternatively, a more instrumental approach to appropriate adaptation at the local level is more likely to succeed as long as local government inclusion is made explicit from the outset.

This chapter discusses the perceived role of equity and justice regarding national adaptation policy at the federal level and adaptation practices in eight local government areas in southeast Nigeria. With the use of a qualitative approach through interview and document analysis, this chapter explores the principles of equity and justice in policies and practices of climate change adaptation in Nigeria. 


\section{Conceptualizing Justice and Equity as It Relates to Climate Change Adaptation}

Climate change issues give concern for different types of justice: distributive, procedural, recognition, compensatory, and restitutive justice (Ciplet and Roberts 2017; Khan et al. 2019; Klinsky and Dowlatabadi 2009; Rawls 1971). The basic structure in the subject of climate change justice here is that different communities experience differentiated impacts of climate variability in part by the political system as well as by economic and social circumstances. This differentiated physical and social vulnerability to climate change impacts create deep inequalities between developing and developed countries. Vulnerable developing countries lack the tools and adaptive capacity required to develop the appropriate response to climate risks. The development of tools and adaptive capacity both at the local and national level has been a significant focus on global adaptation, especially regarding equity and justice. However, equity and justice issues of adaptation are more readily discussed at the global, regional, and national levels than at the local level (Thomas and Twyman 2005), even though adaptation practices are undertaken at the local level.

At the global level, the differentiated vulnerability to the impact of climate issues was brought to the international community's attention in November 2006 at the United Nations Framework Convention on Climate Change (UNFCCC) held in Nairobi, intending to identify situations that increase or reduce the capacity to adapt (Vogel et al. 2007). It was then argued that adaptation would promote benefits that can lead to equitable and sustainable development (Adger et al. 2009). The 2015 Paris Agreement includes a global goal on adaptation through reducing vulnerability to climatic impacts, reinforcing adaptive capacity, and strengthening resilience (International Summit on Climate Change held in Paris 2015). One of the commitments of developed countries under the UNFCCC is to assist developing countries to meet their adaptation cost. If more impoverished country gains access to adaptation funds through equity and justice schemes, adaptation can be improved. Global governance is considered especially relevant for Nigeria and other developing countries, as these countries are already struggling to meet climate change's security challenges (Nightingale 2017; Nath and Behera 2011). The principle of environmental justice is focused on the existence of inequity in the distribution of environmental hazards, where the environment is understood to create a condition for social justice (Schlosberg 2013). As climate change increases, environmental justice is given more broad consideration with a growing focus on sustainability and transformative politics and practice to affirm the socio-ecological unity and the interdependence of all species.

There are essential points to why equity and justice have become two crucial concepts in climate change adaptation discourse at the global and national levels. First is the principle of justice, which emerges as a reaction to the claim that devastating climate extremes such as flood, drought, and desertification made worse by climate change pose additional negative implications for vulnerable developing countries and poverty-affected communities (Nay et al. 2014). The 
susceptibility to climate risk goes beyond biophysical vulnerability to include human well-being, social, economic, and political factors underlying social vulnerability (Kelly and Adger 2000; Otto et al. 2017), which put vulnerable countries in a constant state of crises. Therefore, adaptation should be evaluated based on justice criteria that would benefit all groups of society as well as the future generation by providing the information and resources needed for adaptation, especially for those most vulnerable to climate change impacts.

Second, equity is a concept referring to fairness in the distribution of outcomes or distributive equity (Miller 1992). As regards climate change, Nay et al. (2014) argue that developing economies depend more on climate-sensitive activities that are more impacted by climate variability. They argue further that these developing economies also lack the political and organizational capacity to adapt to climatic impacts. Thus, the outcome of the equity principle should ensure that:

- The vulnerable are treated fairly for unduly bearing the burdens of climate change impacts

- There is an inclusive decision-making process

- There is an inclusive framework for taking and facilitating adaptation action

- There is a relationship between climate change adaptation and other factors that affect livelihoods (McManus et al. 2014)

However, within these developing countries, the social, institutional, and political structures can play an essential role in climate change adaptation. The relationships that exist between the individuals, the communities, and the state are also essential. Thus, adaptation at the local government is often enabled or hindered by other issues such as social structures, power relations, political and institutional structures, as well as the broader higher level of governance arrangements (Lawrence et al. 2015; Simonsson et al. 2011). These relationships often reaffirm the status quo and are likely to influence the issues of equity and justice in local adaptation practices. According to Eriksen et al. 2015, injustice and unfairness exist when the politically powerful actors set up institutions that advance agendas that exclude local knowledge, needs, and voices of the marginalized in adaptation decision-making. These powerful actors with authority further influence adaptation by claiming the right to legitimize or undermine different types of knowledge (Eriksen et al. 2015). Adaptation policies are often designed at the national level and may disproportionately affect vulnerable communities if they are excluded during policy design (Urwin and Jordan 2008). Understanding the local context of vulnerability through local participation in adaptation policies is essential for equitable and justifiable adaptation. This implies a process of social interaction and joint decision-making by stakeholders across governance scale in adaptation. However, from a systems perspective, one of the challenges facing such provision is associated with the complexity of social interactions involved in multilevel adaptation decision-making. 


\section{Climate Change in Nigeria}

Nigeria is one of the most vulnerable countries and is highly dependent on climatesensitive sectors. The country is located in the tropics that give her a hot tropical climate, consisting of variable rainy and dry seasons depending on location. Given the country's climatological cycle and size, there is a considerable range in total annual rainfall across Nigeria, from south to north, and in some regions from east to west. Wet and dry season prevails in the east and west, while a steppe climate with little precipitation is found in the far north. Temperature and humidity remain relatively constant throughout the year in the south, while the season varies considerably in the north (Ajayi et al. 2019). The most significant total precipitation is in the southeast along the coast around Bonny (south of Port Harcourt) and east of Calabar with annual rainfall around 4,000 millimetres ( $\mathrm{mm})$. The regularity of drought periods has been among the most notable aspects of Nigeria's climate in recent years, particularly in the north's drier regions (Akande et al. 2017; Haider 2019). These droughts indicate the considerable variability of climate across tropical Africa and severely affect the drier margins of agricultural zones occupied primarily by pastoral groups.

The southeast is one of the most developed regions in Nigeria, with the secondhighest population density. In 2015, the southeast had a total population of 40 million. Southeast Nigeria falls within the latitude of $6^{\prime} \mathrm{N}$ and $8^{\prime} \mathrm{N}$ and longitude of $4^{\prime} 30^{\prime} \mathrm{E}$ and $7^{\prime} 30^{\prime} \mathrm{E}$, describing the country's inland region. Southeast Nigeria is of the wet tropical type climate with mean annual temperatures between $21^{\circ} \mathrm{C}$ and $34^{\circ}$ C. The temperature is highest around March in the southeast (Iloeje 2009). The mean minimum temperature is relatively close to the coastal area, with annual rainfall exceeding $3500 \mathrm{~mm}$ (Njoku 2006; Nwagbara et al. 2013). In recent years, rainfall has become significantly more substantial in the southeast. In 2012, River Niger reached a record of $12.84 \mathrm{~m}$ above sea level. Water levels have also risen in upstream Cameroon, Mali, and Niger. These countries feed the River Niger and River Benue, which flow through Nigeria. River Niger flows through the southeast region leading to severe flooding. In 2012, flooding led to two million displacements and three hundred and sixty-three (363) deaths. In 2017, 12 states, including states in the southeast, were severely affected, leading to 200 deaths and over 600,000 displacements (Orji 2018). As climate change leads to more rainfall, floods disasters are becoming more devastating in Nigeria, especially in the southeast region. The southeastern region is also exposed to mild drought during the dry season.

\section{Preparing for Climate Change Adaptation in Nigeria}

Nigerian started showing a keen interest in climate change issues since 1994. The first national climate communication in 2003 was aimed at shedding more light on the consequences of climate change and its impact on developmental goals. With the support of development partners such as the United Nations Development Program (UNDP), the European Union (EU), United States Agency for International 
Development (USAID), as well as intergovernmental, regional organizations and nongovernmental agencies, several climate change adaptation strategies and policies have been designed and approved. Nigeria initiated a comprehensive planning process for adaptation by developing the National Adaptation Strategy and Plan of Action on Climate Change for Nigeria (NASPA-CCN). Prioritized adaptation measures in the NASPA-CCN report tend to focus on agriculture, forestry, water resources, human health, human settlement, energy, transportation and communication, industry, disaster and security, livelihoods, vulnerable groups, and education. In NASPA-CCN report, there is a recognition that climate change adaptation can best be achieved through multilevel effort requiring global, national, state, local government, nongovernmental, and civil society coordination (BNRCC 2011). In addition to this, Nigeria has instituted policies and established climate change institutions to aid adaptation. Policies such as National Policy on Erosion and Flood Control, National Water Policy, Nigeria Drought Preparedness Plan, National Forest Policy, National Health Policy, the National Policy on Environment supports (for prevention and management of disasters such as floods, drought, and desertification) and Nigeria's Agricultural Policy were developed to protect agricultural land resources from drought, desert encroachment, soil erosion, and floods (BNRCC 2011). Nigeria has established a climate change framework such as the National Framework for Application of Climate Services - NFACS (to reduce communities' vulnerability by implementing the National Agricultural Resilience Framework for the agricultural sector). Nigeria has also established a climate change department under the federal ministry of environment. The country relies on NIMET (Nigerian Meteorological Agency) and NEMA (National Emergency and Management Agency) for climate-related disaster warnings, prevention, and response. At the state level, departments of climate change are functional in some states and nonfunctional in others. There are no known climate change departments at the local government areas; hence, exiting ministries are carrying out adaptation actions.

\section{Exploring the Equity and Justice Perspective of Climate Change Adaptation in Nigeria}

This section of the chapter takes an equity and justice perspective of adaptation policy and practice in Nigeria, which provides a useful framework for understanding the factors that promote or hinder local government adaptation. The local government areas that are the focus of the chapter are situated in the southeast zone, where the population is (a) vulnerable to climate-related floods and mild droughts, (b) lack adaptive capacity, and (c) agitating for separation from Nigeria due to poor social and political representation. Interviews, observation, and document analyses were used as the primary data sources to explore the perceived impact of equity and justice on national adaptation policies and local adaptation practices in southeast Nigeria. This chapter analyzed the national adaptation plan and other important documents. The key documents analyzed include the National Adaptation Strategy and Plan of action on Climate Change for Nigeria (NASPA-CCN) and 


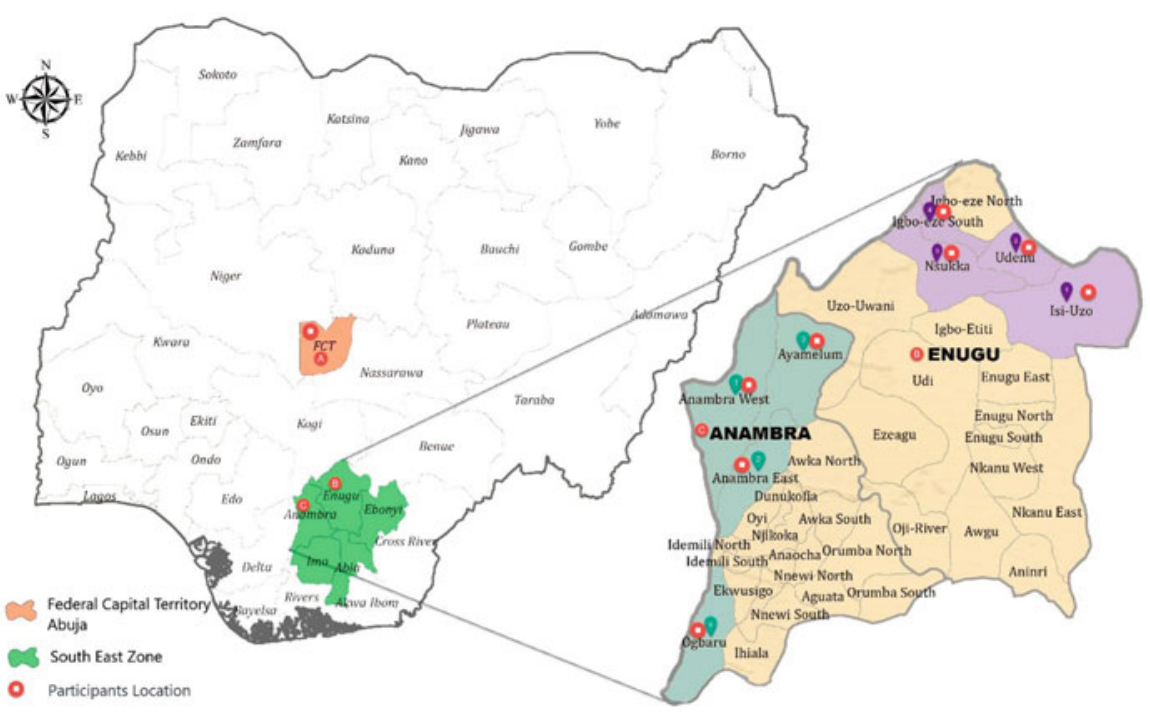

Fig. 1 Map of Nigeria showing the participant's locations

Nigeria Intended Nationally Determined Contribution (INDC 2016). Other documents include scientific articles, policy documents, newspapers, conference speeches, and media contents (Fig. 1).

Interviews and observations were carried out between September 2017 and January 2018. The interview was conducted $(n=52)$ with actors working at the federal, the state, and the local government parastatals. At the national level, ten participants from the federal department of climate change were interviewed. These federal-level participants are labeled FGP (Federal government participant). At the regional level, ten participants from two states in the southeast (Anambra and Enugu state) were interviewed, where five participants were selected from each state. These participants are involved in adaptation across the state ministry of ecology, environment and climate change, the state ministry of works, and the state emergency management agency (SEMA). The state-level participants are labeled SGP (state government participants). At the local government level, 32 participants were interviewed from eight local government areas in southeast. Four experts were selected from each of the eight local government areas. These local government-level participants are labeled LGP (Local government participants). Among these participants are engineers involved in areal planning and infrastructural management, officials engaged in environmental protection, and local emergency management agencies (LEMA). Four of the local government areas, Anambra east, Anambra west, Ayamelum, and Ogbaru, are situated very close to water bodies. With the majority of the population living near the riverine area, flooding is the largest source of climate-related losses. The other four local government areas, IgboEze south, Isiuzo, Nsukka, and Udenu, are situated in highlands where both floods and mild droughts are sources of climate-related losses affecting the population. 
Flood and drought in the southeast impact livelihood, health, crop production, livestock, groundwater dryness, and infrastructure damage. Interview questions focused primarily on how fair adaptation policies are for local government adaptation practices.

The observation was used to collect data on the adaptation practices and activities designed to cope with climate-related disasters. Data obtained through the observation method were noted and analyzed based on a follow-up question for confirmation. The interview, observation, and document analysis data were coded and categorized using Nvivo 11 . The data was identified and categorized thematically using the inductive and data-oriented approach. The findings will be analyzed using the following questions as a structuring tool: what are the physiological and social vulnerability of climate change in the eight southeast local government areas in Nigeria? How is Nigeria adapting to climate change impacts? Who is responsible for adaptation policies and practices? What role do the principles of equity and justice play in adaptation in Nigeria's local government areas? These questions would be explored in three subsections. The first section will give an account of the vulnerability of local government areas to climate change. The second subsection will explain how global adaptation is affecting Nigeria's adaptation policy and practices. The last section will then explain the effect of global equity and justice on local adaptation practices.

\section{Vulnerability and Impact of Climate Change in Nigeria}

Climate change in Nigeria leads to changes in the frequency and intensity of weather and climate extremes. Nigeria's climate extremes hit people in multiple different ways. Warm temperatures cause more evaporation of water, while changes in precipitation lead to heavy rain but also swings into drought conditions. Nigeria is one of the most vulnerable countries to climate variability (IPCC 2014). The most frequently cited vulnerability is sea level rise, floods, droughts, sandstorms, landslides, erosion, intensified desertification, and general land degradation (Medugu et al. 2010). These extreme events have broad consequences for farmlands, livestock, and built infrastructures such as buildings, roads, and railways, as well as fundamental societal concerns, such as disputes over environmental resources, food security, water security, health implications, loss of livelihoods, internal and external migration, and loss of life (BNRCC 2011; IPCC 2014). The broad consequences of climate change make it imperative to assess the level of a country's vulnerability to climate change and capacity and readiness for adaptability. This chapter identified vulnerability to climate change at the national, regional, and local levels. Some vulnerability factors are frequently identified across all three scales: poverty, access to resources, livelihood opportunities, and health. Vulnerability to climate change is distributed disproportionally in Nigeria. The northeast and northwest zones are vulnerable to desertification, heat wave, loss of freshwater, intensive drought, bush burning, loss of arable lands, and livestock loss. The southeast and southwest are vulnerable to sea level rise and salinization, intensive rainfalls, floods, and damages 
to built infrastructures. It would be nearly impossible for preparation to be made towards adapting to these changes if the vulnerability is not adequately understood, especially from the angle of the most affected parties at the local level.

The IPCC conceptualizes vulnerability as a function of the state of a social system and the biophysical nature of climate change effects that the system face (IPCC 2007). Vulnerable to climatic impacts, Nigeria covers different frameworks. These include risk hazards, political ecology, and socio-ecological system frameworks. Within the risk and hazard field, vulnerability is the susceptibility of people and things to losses attributable to a given level of danger, a given probability that a hazard would manifest itself in a particular way, and with a particular magnitude (Alexander 2002: 29). This field of vulnerability often neglects to address how human contribute to climatic hazards as well as the societal context in which climate hazards takes place. In political ecology, vulnerability is a characteristic of a person or group and their situation that influences their capacity to anticipate, cope with, resist, and recover from the impact of a natural hazard (Wisner et al. 2004). In the social-ecological system framework, vulnerability is a state of susceptibility to harm from exposure to stress associated with environmental and social change and the absence of capacity to adapt (Adger et al. 2006). Multiple factors such as environmental exposure, socioeconomic, political, and cultural factors operating at different levels drive vulnerability in Nigeria's local government areas. Climate hazards only lead to disaster if there is biophysical or/and social vulnerability. Biophysical vulnerability to climate change is understood as a function of environmental exposure, while the social vulnerability is a function of socioeconomic, political, and cultural characteristics of a society (Otto et al. 2017).

In Nigeria, vulnerability plays out locally. This chapter attempt an assessment of some local government areas' vulnerability to climate-related flood and drought around two dimensions, biophysical vulnerability and social vulnerability. Results show some similarities in the participant's perception of climatic impacts and adaptation measures.

Table 1 shows that flooding is the largest source of climate-related losses in four low land, local government areas in the southeast, as the participants explained. With an estimated $30 \%$ of the population living near the riverine area, in Anambra east, Anambra west, Ayamelum, and Ogbaru, loss of house settlement, loss of farmland, transportation, limited energy supply, and erosion are constant plight experienced by local communities. Out of 16 participants from low land, local government areas 14 have experienced vulnerability to flooding while 2 knows people that have experienced flood vulnerability. LG participants explained that during flooding, the only transportation system is local boats. However, they argue that using resilient structures such as iron and other metallic products to construct roads and bridges can make the situation better. Flooding causes desperate living conditions leading to the temporal fleeing of millions of people. The electric power supply in the southeast is limited at ordinary times. Flood hazards negatively influence the already limited power supply, forcing households and businesses to use generators that emit $\mathrm{CO} 2$ and other dangerous gasses to the detriment of human health and environmental safety. 


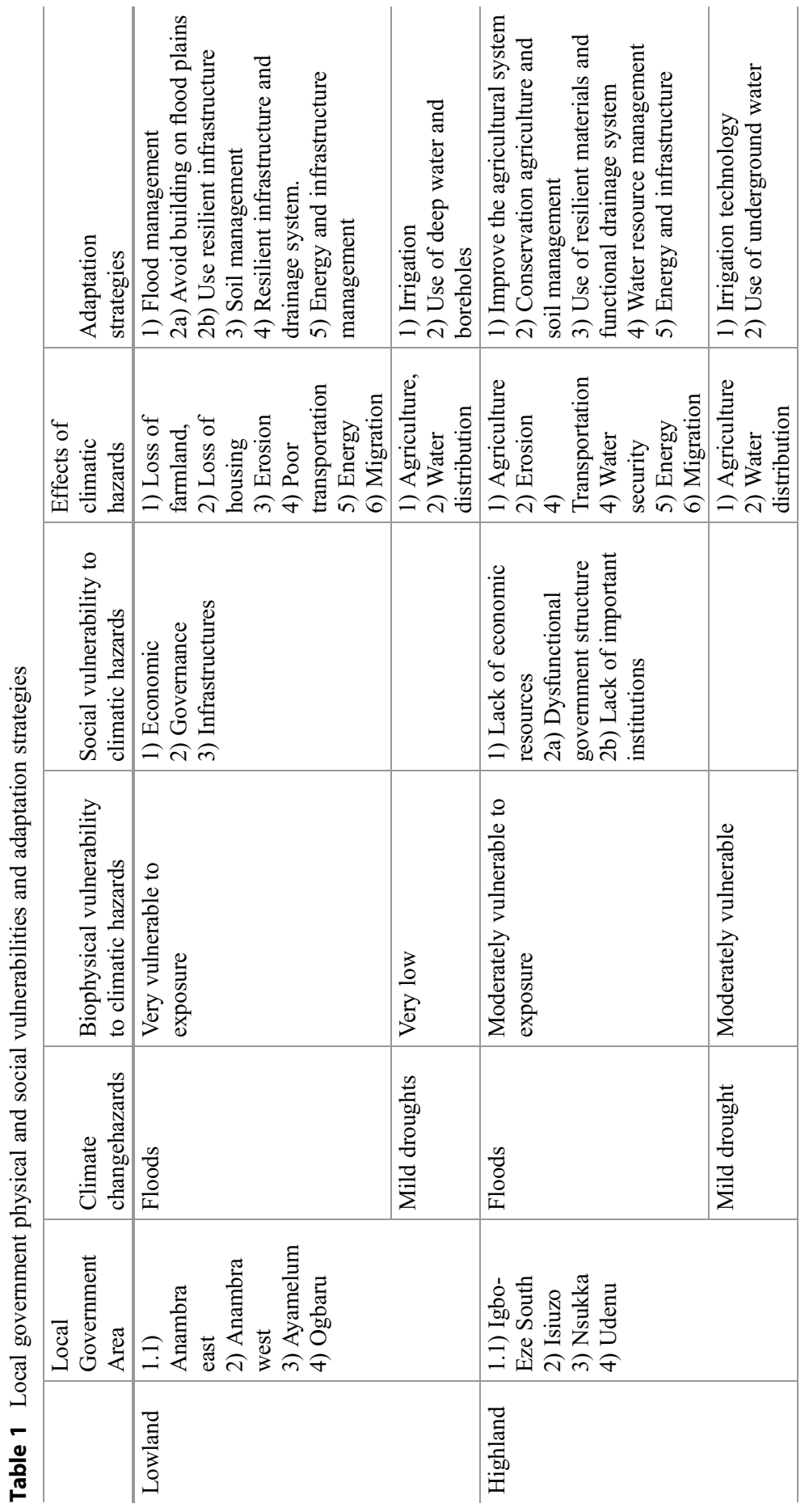


Table 1 illustrates the frequently identified adaptation strategies used to adapt to the effect of climatic hazards. The various adaptation measures identified by LG participants are flood management, town planning, and waste management. Flood management takes place through the construction of an effective drainage system. LGP participants explained that the local communities' drainage system is weak as some drainage systems are poorly constructed. Rainwater leads to overflow and flood incidents because the drainage systems are often not appropriately channeled. Poor town planning leads to improper house settlements where people construct houses on floodplains. LGP participants agree that communities must adhere to town planning to avoid the loss of house settlements. Proper town planning discourages people from building on floodplains and using resilient structures that can withstand extreme weather variability. Poor waste management leads to people's disposal of waste when it is raining. These wastes block the drainage system and contribute to flooding.

Erosion is another hazard linked to climate variability in the low land, local government areas of southeast. LGP participants explain that people have lost their houses and farmlands to erosion. They also explain that erosion losses are not as severe as losses from the flood as erosion occurs slowly. LGP mentioned soil management and planting of trees as necessary measures used to reduce erosion. In Anambra east, Anambra west, and Ogbaru, the LGP participants explained that trees' planting is not sustainable due to firewood consumption.

Slow onset events such as drought are also having a substantial impact on crop production, livestock, and water distribution in low land, local government areas but at a deficient level. The use of irrigation and digging for clean water is common in these local government areas during drought. However, LGP explained that the use of irrigation is constrained by limited irrigation facilities based on available resources.

In the local government areas located in highlands, mainly: Igbo-Eze south, Isiuzo, Nsukka, and Udenu, the LGP participants explained that households are not often in danger of losing their homes due to moderate flooding instead, it is agriculture, gully erosion, road infrastructures, and energy distribution that are impacted. There is an uneven distribution of rainfall, and participants noted that the length of dry periods is on the increase. LGP participants in the local government located in highlands note that drought is a climatic hazard, leading to water shortage, with notable negative impacts on the farmers' crops, livestock, and income. These participants suggest that rainfall is often not sufficient for their agricultural production and household needs. Field observation revealed that different household sources water from streams and boreholes.

Table 1 illustrates that apart from massive flooding in the low land local government area, there are similarities in climate change challenges as well as similarities in adaptation measures in both the low and high land local government areas. The most remarkable difference between the low land local government areas and the high land local government areas is their preparedness. LGP explained that even though climate change is leading to unpredictable rainy seasons, those in riverine areas are often more prepared, which inspires more proactive adaptation strategies. In the 
Anam community, people come together to construct tall buildings to adapt to floods. Households are often not caught off guard as they proactively get temporal housing settlements and their boats ready for transportation as soon as flood starts.

In all the local government areas, it was indicated that the adoption of the adaptation measures frequently mentioned is moderate due to lack of resources. Though communities in the southeast are already implementing numerous strategies to cope with climate change, LG participants agree that the adaptation measures are carried out on individual, group, and community levels. The reasons given for low adaptive capacity vary from access to funds, lack of climate change awareness, and lack of human resources in the face of climate change. Nigeria context throws light into how physical vulnerability interacts with social vulnerability in climate change adaptation issues. Looking at climate change as both biophysical and social problems allows political and socioeconomic measures to evaluate the effects on the poor and vulnerable.

\section{Adaptation Policies and Practices in Nigeria}

\section{Policy Implications of Adaptation Governance in Nigeria}

Since UNFCCC first conference in 1995, nations have convened to institute and implement binding climate agreements, either as regards to mitigation or adaptation. These binding agreements have lasting impacts on how global climate treaties and national climate policies evolve. These agreements also help determine how financial resources to adapt are distributed (Gurwitt et al. 2017). Nigeria has been engaging in international climate policy negotiations since 1994 when the country becomes a party to the United Nations Framework Convention to Climate Change (UNFCCC). Nigeria ratified Kyoto Protocol in 2004 and submitted the first national climate communication in 2003 and the second national communication in 2014. United Nations Framework Convention on Climate Change provides funding to developing countries with National Adaptation Plans of Action (NAPAs). Under such treaties, countries are required to develop NAPA to adapt to climate change. Nigeria prepared its National Climate Change Action Plan in 2011, which led to the Nigeria Climate Change Policy's approval in 2012.

NAPA provides Nigeria and other least developed countries (LDCs) with an opportunity to meet their urgent and immediate needs for adapting to climate change. In 2015, Nigeria prepared its Intended Nationally Determined Contribution (INDC) and signed the Paris Agreement in 2017. These policy documents' common objective is to demonstrate political commitment to adaptation and communicate the overall government approach to adaptation. Nigeria's policy plan helps identify climate change impacts and vulnerabilities and identify areas where the country's adaptive capacity can be improved (INDC 2016). Adaptation policy targets different sectors of Nigeria's society such as agriculture, freshwater, coastal resources, forest, biodiversity, health and sanitation, human settlement, energy, transportation and communication, industry and commerce, disaster, migration and security, livelihood, education, and vulnerable groups. Nigeria Climate Change Action Plan and INDC 
report recognize that achieving an adaptation goal would require international support due to its low adaptive capacity. As explained in (BNRCC 2011), Nigeria National Adaptation Strategy and Plan of Action on Climate Change, Nigeria seeks to:

- Detail financial needs assessment to accurately determine the economic costs of climate change adaptation

- Revise the National Fiscal Policy to incorporate the cost of climate change adaptation

- Create a national financing mechanism to support real adaptation needs

- Access necessary international adaptation funding and technologies and manage those funds well

The above are top-down measures that would trickle down to the local level. Within the Nigerian climate policy document, the role of the federal government, the state government, the local government, the private sector, and civil society are made explicit. The federal government is responsible for instituting policies while the local government is responsible for implementing adaptation policies. The issues emphasized in Nigeria's Plan of Action are issues of collaboration, transparency, and finance. BNRCC (2011) report indicates that the federal and state governments would collaborate with the local government to strengthen communities' adaptive capacity by providing:

- Information and technological know-how, facilitating financial and other measures

- Put in place adaptation communication to allow all stakeholders to participate actively in climate change adaptation (NASPA-CCN, 2011)

However, FG participant notes that Nigeria's adaptation policy is increasingly influenced by intergovernmental organizations, as the submission of these documents and reports is relevant to obtain proper support. FG and SG participants explained that adaptation policies encompass climate change issues affecting all Nigerians and strategies to solve those issues. On the other hand, LG participants indicate that the adaptation policy is a one-fit document that lacks knowledge of local problems and solutions. Proposals for an international climate change adaptation policy recognize local representation, even though there are hardly any inquiries to ensure local representation inclusion.

\section{Actors Perspective on Adaptation Governance in Nigeria}

FG, SG, and LG participants were asked about their role in climate change adaptation practices. All the FG participants claim that they have engaged in different adaptation practices. Twenty percent of SG participants admitted that they had taken no action but are aware of several adaptation projects. The LG participants claim to 
have engaged in different adaptation activities such as road construction, house construction, helping community members during rescue operations, and helping to deliver aids.

When asked about who is responsible for climate change adaptation practices, FG and SG participants were quick to point fingers to developed nations. They claim that Nigeria has benefited from international climate change adaptation funds; however, LG participants explain that individuals and groups carry out adaptation practices on a low scale, as the funds have not translated into effective adaptation practices in the local government areas in the southeast. All participants perceived the role of local government in different ways. The FG participants thought that the local government is getting the necessary resources to help communities address climate change issues. The SG participants are aware of the local government plight as it relates financial and technological resources but insists that the local government is in the position to help local communities adapt.

Interestingly, LG participants think that local government programs to address climate change are indigent. The main reason for this perception appeared to be communication and governance issues. Communication issues bother on perceived lack of consultation and transparency on the part of the state and federal government. The reason for the governance issue included the perception of autonomy and mistrust of the state and federal government. LG participants expressed that federal and state government interferes in local government matters.

When asked about the collaboration in climate change adaptation, the FG participants rate collaboration between the three government levels as excellent. The SG participants rate the relationship between the federal and state government levels as good and state with local government as fair. The LG participants thought there is almost zero collaboration between the local government and other government levels. Eighty percent of LG participants describe the collaboration between the local and the other government levels as servant-master collaboration.

\section{Equity and Justice in Adaptation Policies and Practices in Nigeria}

Global equity and justice are essential to plan and mobilize the resources needed to implement adaptation actions. However, it could not be straightforward for international policy to lay claim in sovereign affairs taking place within a sovereign territory. The dilemma of equity and justice in climate change adaptation takes different dimensions in Nigeria. In Nigeria, like many developing countries, contributing minimally to climate change issues, climate variability has become a significant threat to survival and sustainable development, especially for vulnerable individuals and communities (Ilevbare 2019). Nigeria is vulnerable to climate security issues with low adaptive capacity.

On the one hand, there is a top-down international rule system to promote adaptation ambition and accountability. On the other hand, climate change implicates domestic sensitivities in Nigeria. There is a diverging perception of how global equity and justice scheme is impacting Nigeria adaptation policies and practices. The 
result indicates that there is a fundamental difference between interpretations of equity and justice by FG, SG, and LG participants.

In this section, a perceived overview of adaptation policy and adaptation practices will be presented. A shared perspective on equity and justice is essential not only for transparency but also for ensuring that fair and just adaptation reaches the most vulnerable people. Those at the federal and state level view adaptation as the responsibility of the developed country that has contributed most to climate change issues, while those at the local level think adaptation is the responsibility of the national and state government. This view is reflected in the policy report, which indicates that Nigeria needs assistance from international, regional, and nongovernmental organizations to reach its intended adaptation goals (INDC 2016). LG participants indicate that the vulnerable local government is struggling to meet adaptation requirements despite the fund Nigeria government acquires for adaptation projects. Results show that there are several reasons why justice eludes the vulnerable communities. FG participants claim that Nigeria, as a country, still lacks the technological and financial resources despite funding from international and regional agencies. SG and LG participants agree that resources for adaptation are lacking in all government levels but argue that other factors play a significant role in poor adaptation practices. The common factors mentioned are the institutional context, social structure, power relations, and fiscal capacity for the effective management of natural resources and adaptation funds.

In Nigeria, social structure can be viewed through institutionalized relationships organized around family, religion, education, politics, media, and economy. These institutions organize the social relationship of the southeast to other regions of Nigeria. The southeast and southwest are predominantly Christians, while the northeast and northwest are predominantly Muslims. The different zones with various ethno cultural groups merged into one country in 1914. The different zones have different tribal groups, languages, and cultures. The differences in culture, politics, and tribal identification affect people's relationships with one another. Culture and ethnoreligious politics influence the distribution of resources in Nigeria (Brown 2013).

It was previously found that political corruption and bad leadership affect the southeast zone (Ogundiya 2010). Southeast is a zone where an estimated 50\% of the population feel that they are not part of Nigeria. This resentment can be attributed to the Biafra Civil War that killed millions of southeasterners from July 1967 to January 1970. The southeast feels marginalized, leading to some citizens advocating for fresh separation (Olajide et al. 2018). LG participants explained that due to Nigeria's political structure, the southeast lacks resources and infrastructures, which makes adaptation more difficult. Unequal policies and patterns of government structure driven by national and regional political and economic priorities benefit a particular segment of society while making others more vulnerable. Another issue in the southeast is that the service and industry sector are paid more attention at the expense of small-scale agriculture and fisheries (Nzeadibe et al. 2011), even though LG participants note that the farming communities are the most vulnerable in the southeast. 
Nigeria operates federalism with an overconcentration of power at the national level (Akinsanya 1999). In this aspect, the politicians at the national level hold a more considerable amount of power to determine what happens to the vulnerable local population as regards climate change impact. Local government lacks autonomy and depends on the state and national government. This dependency leads to weak institutionalization and local government underutilization, allowing constant intervention from the state and federal government (Acheoah 2018). Adaptation policies are formulated at the state and national levels while adaptation practices take place at the local level. LG participants explained that local knowledge is often not sought during policy formulation, making it challenging to implement such policies in practice. When the state and federal government neglect the most vulnerable participation at the local government, vital communication that encourages collaboration is lost.

Interview and field observation indicate that Nigeria's institutional capacity for climate change adaptation at the federal, state, and local government level is undeveloped and weak. Oulu (2015) argues that establishing effective institutional frameworks is crucial for climate change adaptation. Even with the presence of adaptation policy and climate change department at the federal level, adaptation practices are carried out by the existing National or State Emergency Management Agency (NEMA and SEMA). These two agencies were not designed for climate change adaptation. Only two of the local government areas in the southeast have a Local Emergency Management Agency. NEMA is an existing risk management agency that takes the issue of climate change adaptation as one of its many functions. Climate change adaptation and mitigation goals are now assigned to the ministry and department of the environment. However, LG, SG, and FG participants explain that proven competencies and technological resources in the existing institutions are low.

The budgetary constraint is one of the factors inhibiting adaptation in local communities in Nigeria. However, participants from the federal, the state, and the local government areas have different explanations on how budget constraints hinder adaptation. FG and SG participants claim that budgetary constraints are because of Nigeria's poor economic condition. The LG participants attribute budget constraints to the local government's lack of financial independence. LG participants suggest that the local government also lacked autonomy that contributes to its lack of financial independence required to tackle the issue of climate change adaptation. Fieldwork observation indicates that local government relies on SEMA for relief and settlements for internally displaced people. LG participants explain that the local actors that know the communities well are often not consulted during these visits.

\section{Conclusion}

This chapter recognizes that adaptation practices in local governments in southeast Nigeria have equity and justice implications. Environmental equity and justice focus on ensuring that the most vulnerable communities and countries are not left to bear the burden alone. It was argued that climate justice should include mechanisms to ensure that most impacted at the local level have their interests considered (Thomas 
and Twyman 2005). However, this chapter found that vulnerability to climate change is mostly experienced at the local level, with the burden of adaptation falling disproportionately on the local government areas. Though Nigeria has developed adaptation policies that detail strategies to reduce and avoid climatic impacts, the local government is excluded from decision-making in adaptation policies, and thereby their vulnerability is often not reflected in the policy documents. This is because climate change adaptation policies and practices at the national level of governance are not open for representative dialogue, especially with the local government's participation. This chapter argues that by excluding the local government in the southeast in adaptation decision-making, the national adaptation plan and policies ignore local adaptation needs and knowledge and do not reflect local vulnerability. Beyond local participation, the interaction between the national authority and local knowledge needs to rely on fairness and accountability. Unless the most vulnerable adapt, risks associated with climate change could increase vulnerabilities, and more inequality.

Financial and technological resources remain crucial in helping the poor and vulnerable communities adapt to climate change risk and climate security issues. Access to these resources is vital for adaptation practices. The United Nations Framework Convention on Climate Change (UNFCCC) provides funding to ensure that the most vulnerable countries are not left to deal with climate change alone. The inclusion of local government in adaptation decision-making will ensure that global funding is easily translated into local practice and that adaptation resources are correctly channeled. This chapter also indicates that it is essential to understand issues such as social structure, power relations, institutional context, and budgetary constraints and how they affect local government adaptation. Thus, local government adaptation practices are not independent of preexisting sociopolitical and governance structures in developing countries like Nigeria. This chapter recommends the local government's inclusion in decision-making and formal adaptation governance to encourage partnership and transparency.

\section{References}

Acheoah OA (2018) Local government: the underutilized governance structure in Nigeria. Arts Soc Sci J 9(5):1-4

Adger WN, Paavola J, Huq S (2006) Towards justice in adaptation to climate change. In: Adger WN, Paavola J, Huq S, Mace MJ (eds) Fairness in adaptation to climate change. The MIT Press, Cambridge, MA, pp 1-19

Adger WN, Lorenzoni I, O’Brien KL (2009) Adaptation now. In: Adger WN, Lorenzoni I, O’Brien KL (eds) Adapting to climate change: thresholds, values, governance. Cambridge University Press, Cambridge/New York, pp 1-22

Ajayi JFA, Kirk-Greene AHM, Udo RK, Falola TO (2019) Nigeria. Encyclopædia Britannica. Retrieved from https://www.britannica.com/place/Nigeria/Resources-and-power

Akande A, Costa AC, Mateu J, Henriques R (2017) Geospatial analysis of extreme weather events in Nigeria (1985-2015) using self-organizing maps. Adv Meteorol 2017:8576150. https://doi. org/10.1155/2017/8576150

Akinsanya A (1999) Intergovernmental relations in Africa under the 1995 draft constitution. In: Uya E, Uchenna V (eds) Issues in the 1995 Nigerian draft constitution. IPPA, Calabar 
Alexander D (2002) Principles of emergency planning and management. Terra Publishing, Harpenden, $\mathrm{p} 29$

Benzie M, Persson $\AA$ (2019) Governing borderless climate risks: moving beyond the territorial framing of adaptation. Int Environ Agreements Polit Law Econ 19(4):369-393. https://doi.org/ 10.1007/s10784-019-09441-y

BNRCC (Building Nigeria's Response to Climate Change) (2011) National adaptation Strategy and Plan of Action on Climate Change for Nigeria (NASPA-CCN). Prepared for the Federal Ministry of Environment Special Climate Change Unit. Available at http://csdevnet.org/wpcontent/uploads/NATIONAL-ADAPTATION-STRATEGY-AND-PLAN-OF-ACTION.pdf

Brown GM (2013) Nigeria political system: an analysis. Int J Humanit Soc Sci 3(10):172-179

Ciplet D, Roberts JT (2017) Climate change and the transition to neoliberal environmental governance. Glob Environ Chang 46:148-156. https://doi.org/10.1016/j.gloenvcha.2017.09. 003

Ciplet D, Roberts JT, Khan M (2013) The politics of international climate adaptation funding: justice and divisions in the greenhouse. Glob Environ Polit 13(1):49-68. https://doi.org/10. 1162/GLEP_a_00153

Corfee-Morlot J, Cochran I, Hallegatte S, Teasdal PJ (2011) Multilevel risk governance and urban adaptation policy. Climate Change 104(1):169-197

Eriksen SH, Nightingale AJ, Eakin H (2015) Reframing adaptation: the political nature of climate change adaptation. Glob Environ Chang 35:523-533. https://doi.org/10.1016/j.gloenvcha.2015. 09.014

Few R, Brown K, Tompkins EL (2007) Public participation and climate change adaptation: avoiding the illusion of inclusion. Clim Pol 7(1):46-59. https://doi.org/10.1080/14693062. 2007.9685637

Gurwitt S, Malkki K, Mitra M (2017) Global issue, developed country bias: the Paris climate conference as covered by daily print news organizations in 13 nations. Clim Chang 143(3):281-296. https://doi.org/10.1007/s10584-017-2004-2

Haider H (2019) Climate change in Nigeria: impacts and responses. K4D helpdesk report 675. Institute of Development Studies, Brighton

Ilevbare FM (2019) Investigating effects of climate change on health Risks in Nigeria (Online First), IntechOpen. https://doi.org/10.5772/intechopen.86912. Available from: https://www. intechopen.com/online-first/investigating-effects-of-climate-change-on-health-risks-in-nigeria

Iloeje NP (2009) A new geography of Nigeria, 5th ed. Longman, Nigeria

INDC (2016) Nigeria's intended nationally determined contribution. Available at http://www.4. unfccc.int/ndcregistry/PublishedDocuments/Nigeria\%20First/Approved\%20Nigeria's\% 20INDC_271115.pdf. Accessed, October 2017

IPCC (2007) Climate change 2007: impacts, adaptation and vulnerability. In: Parry ML, Canziani OF, Palutikof JP, van der Linden PJ, Hanson CE (eds) Contribution of Working Group II to the fourth assessment report of the Intergovernmental Panel on Climate Change. Cambridge University Press, Cambridge, p 976

IPCC (2014) Climate change 2014: impacts, adaptation, and vulnerability. In: Contribution for Working Group II to the fifth assessment report of the Intergovernmental Panel on Climate Change. Cambridge University Press, Cambridge, UK

Kelly PM, Adger WN (2000) Theory and practice in assessing vulnerability to climate change and facilitating adaptation. Clim Chang 47:325-352. https://doi.org/10.1023/A:1005627828199

Khan M, Robinson S-a, Weikmans R, Ciplet D, Roberts JT (2019) Twenty-five years of adaptation finance through a climate justice lens. Clim Chang. https://doi.org/10.1007/s10584-019-02563$\mathrm{x}$

Klinsky S, Dowlatabadi H (2009) Conceptualizations of justice in climate policy. Clim Pol 9 (1):88-108. https://doi.org/10.3763/cpol.2008.0583b.

Lawrence J, Sullivan F, Lash A, Ide G, Cameron C, McGlinchey L (2015) Adapting to changing climate risk by local government in New Zealand: institutional practice barriers and enablers. Local Environ 20(3):298-320. https://doi.org/10.1080/13549839.2013.839643 
Lockwood M, Davidson J, Curtis A, Stratford E, Griffith R (2009) Multi-level environmental governance: lessons from Australian natural resource management. Aust Geogr 40(2):169-186. https://doi.org/10.1080/00049180902964926

McManus P, Shrestha KK, Yoo D (2014) Equity and climate change: local adaptation issues and responses in the City of Lake Macquarie, Australia. Urban Clim:10, 1-10,18. https://doi.org/10. 1016/j.uclim.2014.08.003

Measham T, Preston B, Smith T, Brooke C, Gorddard R, Withycombe G, Morrison C (2011) Adapting to climate change through local municipal planning: barriers and challenges. Mitig Adapt Strateg Glob Chang 16(8):889-909

Medugu IN, Majid RM, Johar F, Choji ID (2010) The role of afforestation programme in combating desertification in Nigeria. Int J Clim Chang Strateg Manag 2(1):35-47. https://doi.org/10.1108/ 17568691011020247

Miller D (1992) Distributive justice: what the people think. Ethics 102(3):555-593. Retrieved March 9, 2020, from http://www.jstor.org/stable/2381840

Moore FC (2012) Negotiating adaptation: norm selection and hybridization in international climate negotiations. Glob Environ Polit 12(4):30-48. https://doi.org/10.1162/GLEP a 00138

Nalau J, Preston BL, Maloney MC (2015) Is adaptation a local responsibility? Environ Sci Pol 48:89-98. https://doi.org/10.1016/j.envsci.2014.12.011

Nath PK, Behera B (2011) A critical review of impact of and adaptation to climate change in developed and developing economies. Environ Dev Sustain 13(1):141-162. https://doi.org/10. 1007/s10668-010-9253-9

Nay JJ, Abkowitz M, Chu E, Gallagher D, Wright H (2014) A review of decision-support models for adaptation to climate change in the context of development. Clim Dev 6 (4):357-367. https://doi.org/10.1080/17565529.2014.912196

Nightingale AJ (2017) Power and politics in climate change adaptation efforts: struggles over authority and recognition in the context of political instability. Geoforum 84:11-20. https://doi. org/10.1016/j.geoforum.2017.05.011

Njoku JD (2006) Analysis of the effect of global warming on forest of southeastern Nigeria using remotely sensed data. A PhD thesis Imo State University, Owerri, Nigeria

Nwagbara MO, Chima GN, Ndukwe-Okoye N (2013) Climate change and soil erosion in the derived savanna of southeastern Nigeria. Being a paper presented at the 37th annual conference of the soil science society of Igeria held at Lafia, Nasara State, 11-15 March

Nzeadibe T, Egbule C, Chukwuone N, Agu V (2011) Climate change awareness and adaptation in the Niger Delta Rgion of Nigeria. African Technology Policy Studies Network, Nairobi

Ogundiya IS (2010) Democracy and good governance: Nigeria's dilemma. Afr J Polit Sci Int Rel 4 (6):201-208

Olajide BE, Quadri MO, Ojakorotu V (2018) Climate change, human security and good governance in Nigeria. Afr Renaiss 15(3):173-196

Orji S (2018) It rains, it pours, it floods: Nigeria's growing seasonal problem. African Argument. Retrieved from https://africanarguments.org/2018/11/15/nigeria-floods-growing-problem/

Otto IM, Reckien D, Reyer CPO, Marcus R, Le Masson V, Jones L, ... Serdeczny O (2017) Social vulnerability to climate change: a review of concepts and evidence. Reg Environ Chang 17 (6):1651-1662. https://doi.org/10.1007/s10113-017-1105-9.

Oulu M (2015) Climate change governance: emerging legal and institutional frameworks for developing countries. In: Leal Filho W (ed) Handbook of climate change adaptation. Springer Berlin Heidelberg, Berlin/Heidelberg, pp 1-20

Paavola J, Adger WN (2006) Fair adaptation to climate change. Ecol Econ 56(4):594-609. https:// doi.org/10.1016/j.ecolecon.2005.03.015

Rauken T, Mydske PK, Winsvold M (2015) Mainstreaming climate change adaptation at the local level. Local Environment 20(4):408-423. https://doi.org/10.1080/13549839.2014.880412

Rawls J (1971) A theory of justice, Revised edn. The Belknap Press of Harvard Press, Cambridge, MA 
Rübbelke DTG (2011) International support of climate change policies in developing countries: strategic, moral and fairness aspects. Ecol Econ 70(8):1470-1480. https://doi.org/10.1016/j. ecolecon.2011.03.007

Saraswat C, Kumar P (2016) Climate justice in lieu of climate change: a sustainable approach to respond to the climate change injustice and an awakening of the environmental movement. Energy Ecol Environ 1(2):67-74. https://doi.org/10.1007/s40974-015-0001-8

Schlosberg D (2013) Theorising environmental justice: the expanding sphere of a discourse. Environ Polit 22(1):37-55. https://doi.org/10.1080/09644016.2013.755387

Simonsson L, Åsa Gerger S, Karin A, Oskar W, Richard J. T. Klein (2011) Perceptions of risk and limits to climate change adaptation: case studies of two Swedish urban regions. In: Ford JD, Berrang-Ford L (eds) Climate change adaptation in developed nations: from theory to practice. Dordrecht: Springer Netherlands, pp 321-334

Stallworthy M (2009) Environmental justice imperatives for an era of climate change. J Law Soc 36(1):55-74

Tabbo AM, Amadou Z (2017) Assessing newly introduced climate change adaptation strategy packages among rural households: evidence from Kaou local government area, Tahoua State, Niger Republic. Jamba (Potchefstroom, South Africa) 9(1):383-383. https://doi.org/10.4102/ jamba.v9i1.383

Thomas DSG, Twyman C (2005) Equity and justice in climate change adaptation amongst naturalresource dependent societies. Glob Environ Chang 15:115-124

Urwin K, Jordan A (2008) Does public policy support or undermine climate change adaptation? Exploring policy interplay across different scales of governance. Glob Environ Chang 18:180-191

Vogel B, Henstra D (2015) Studying local climate adaptation: a heuristic research framework for comparative policy analysis. Glob Environ Chang 31:110-120. https://doi.org/10.1016/j. gloenvcha.2015.01.001

Vogel C, Moser SC, Kasperson RE, Dabelko GD (2007) Linking vulnerability, adaptation, and resilience science to practice: pathways, players, and partnerships. Glob Environ Chang 17 (3):349-364. https://doi.org/10.1016/j.gloenvcha.2007.05.002

Wisner B, Blaikie P, Cannon T, Davis I (2004) At risk: natural hazards, people's vulnerability and disasters, 2nd edn. Routledge, London

Open Access This chapter is licensed under the terms of the Creative Commons Attribution 4.0 International License (http://creativecommons.org/licenses/by/4.0/), which permits use, sharing, adaptation, distribution and reproduction in any medium or format, as long as you give appropriate credit to the original author(s) and the source, provide a link to the Creative Commons license and indicate if changes were made.

The images or other third party material in this chapter are included in the chapter's Creative Commons license, unless indicated otherwise in a credit line to the material. If material is not included in the chapter's Creative Commons license and your intended use is not permitted by statutory regulation or exceeds the permitted use, you will need to obtain permission directly from the copyright holder.

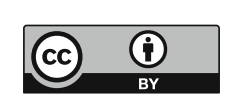

